\title{
Single nucleiotide polymorphisms on exon 3 of leptin gene and their association with growth in Padjadjaran sheep
}

\author{
D. Rahmat*, N. Hilmia and S.K. Bandiati \\ Department of Animal Production, Faculty of Animal Husbandry, Universitas Padjadjaran, \\ Jl. Raya Bandung Sumedang Km 21 Jatinangor Sumedang West Java - Indonesia \\ *Corresponding E-mail: dedi.rahmat@unpad.ac.id
}

Received February 11, 2020; Accepted July 24, 2020

\begin{abstract}
ABSTRAK
Keragaman gen leptin pada beberapa ternak menunjukkan perubahan fungsi fisiologis hormon leptin sebagai anti obesitas. Penelitian ini bertujuan untuk mengetahui keragaman gen Leptin pada exon 3 dan hubungannya dengan bobot badan pada domba Padjadjaran. Sampel DNA diperoleh dari darah 26 ekor domba Padjadjaran jantan umur 1 tahun yang diisolasi menggunakan Metoda Homebrew, DNA target diperbanyak dengan PCR. Data keragaman gen leptin dianalisis dari hasil sekuensing menggunakan metode Sanger dari produk PCR gen leptin exon 3 sepanjang 696 bp. Analisis mutasi titik pada sekuen nukleotide (Single Nucleotide Polymorphisms/SNPs) menggunakan program Bioedit dan MEGA 7. Parameter yang diukur adalah bobot badan dari lahir sampai dengan umur satu tahun. Pengaruh keragaman gen leptin dengan produktivitas dianalisis dengan uji-t tidak berpasangan. Hasil penelitian menunjukkan terdapat SNPs pada gen leptin domba Padjadjaran posisi di exon 3, yaitu g. $170 \mathrm{G}<\mathrm{A}$ dan g. $332 \mathrm{G}<\mathrm{A}$. Kedua mutasi ini merupakan non synonymous mutation karena terdapat perubahan asam amino dari Arginin menjadi Glutamin. Genotyping dilakukan berdasarkan kedua SNPs sehingga diperoleh dua alel $\mathrm{G}$ dan $\mathrm{A}$, masing masing mempunyai frekuensi alel sebesar 0,75 dan 0,25, dengan frekuensi masing masing genotipe, AG dan GG sebesar 0,5. Mutasi titik pada gen leptin exon 3 tidak mempengaruhi bobot badan sampai umur 1 tahun.
\end{abstract}

Kata kunci : domba Padjadjaran, leptin, bobot badan

\section{ABSTRACT}

The diversity of leptin genes in cattle has an impact to the physiological function of the leptin hormone as anti-obesity. This study was aimed to determine polymorphisms of the Leptin gene based on Single Nucleotide Polymorphism on exon $3^{\text {rd }}$ and their effect to body weight, of Padjadjaran sheep. DNA samples were obtained from the blood of 26 Padjadjaran rams 1 years. Data of leptin gene diversity were analyzed from the results of PCR product sequencing by Sanger Methode of $696 \mathrm{bp}$ leptin exon 3. Point mutations (SNPs) on nucleotide sequence were analyzed using Bioedit and MEGA 7 Program. Growth parameters which were measured i.e. monthly body weight gain until one year of age. The association of leptin gene polymorphism with body weight was find out by unpaired $T$ test. The results showed there were SNPs in Leptin gene in exon 3 of Padjadjaran sheep, namely g.170 G>A and g. 332.A> G. Both of these mutations are non-synonymous mutations because there were altered amino acids from Arginine to Glutamine. Genotyping was done based on the two mutations above and got two alleles $\mathrm{G}$ and $\mathrm{A}$, each of which has an allele frequency of 0.75 and 0.25 , with the frequency of each genotype, AG and GG was 0.5. There was not association between SNPs on leptin gene with body weight from birth to 12 months of age.

Keywords: body weight, Leptin, Padjadjaran sheep 


\section{INTRODUCTION}

Lamb and live sheep demand increase since some decade ago in Indonesia, in line with increasing domestic consumption of lamb and high volume of export demand, especially from muslim countries as the biggest importers. This condition should be balanced by improvement on sheep productivity as well as quantity and quality. High productivity can be achieved through genetic improvement, environmental control and their combination. Through the genetic aspect, productivity enhancement is related to selection towards genes that are positively correlate with economic traits.

Molecular genetic technology has support selection at gene or DNA level by analyzing alteration in the nucleotide sequence, like as point mutations at the nucleotide that cause variations (Single Nucleotide Polymorphisms/SNPs). There are two SNPs, synonymous mutation which do not changed encode of amino acids, and nonsynonymous mutation altering amino acids and have to be evaluated their effect on economic traits in between productivity. Selection on genetic level is going to impact to their progeny effectively.

Productivity is a quantitative trait that generally regulated by many genes including groups of encoding genes, like as growth hormone (GH), Insulin Like Growth Factor (IGF) (Martinez and Saladana, 2012), and leptin (Sainz, 2015). Furthermore, Wasim (2015) stated that leptin contributs in growth through signals of leptin as an obese hormone and has dominantly a major role in balancing of food intake and energy expenditure to regulate body weight on physiological process. The study of association leptin gene polymorphism with productivity has been done in cattle. The research of Woronuk et al. (2012) on cattle revealed SNP on leptin gene had a significant correlation with body weight and backfat depth. Foote et al. (2015) declared in finishing beef cattle, leptin concentrations could be a useful physiological marker for growth and feed efficiency.

Leptin genes in sheep are located on the $4^{\text {th }}$ chromosome, consist of three exons and two introns along $16 \mathrm{~kb}$ genomic DNA. The target of SNP analysis in this study is SNPs in exon $3^{\text {rd }}$. Several studies in sheep showed there were mutations in the exon 3 of leptin gene, on g.170 $\mathrm{G}>\mathrm{A}$ and g.332.A $>\mathrm{G}$. changes in nitrogen bases from guanin to adenine or vice versa. Both of the point mutations are a non synonymous mutation, resulting in amino acids changes from arginine to glutamine and vice versa. The study in three breeds of Iranian sheep, those were Shal, Zel and Zandi showed there were two SNPs A113G and $\mathrm{T} 165 \mathrm{C}$, both of them were a transitions positions (Barzehkar et al., 2009). Wang et al. (2015) found two SNPs which are associated with growth trait, i.e. g. $1642 \mathrm{G}>\mathrm{A}$ and g.3190 $\mathrm{G}>\mathrm{A}$ in Chinese Nanjiang Yellow Goat. Furthermore, in Arabian sheep Najdi and Naeimi (Mahmoud et al., 2014), and in Sanjabi sheep (Bakhtiar et al., 2017) were found two nonsynonymous mutations of g. $170 \mathrm{G}<\mathrm{A}$ and g. $332 \mathrm{G}<\mathrm{A}$. Therefore Caprine and Ovine $L E P$ gene polymorphism as a genetic marker may be useful in goat and sheep for future breeding programs to increased their production.

There is a limited information relating to leptin gene polymorphism based on SNPs in Indonesian local sheep. The alleles determination in this study was based on non-synonymous mutation of $\mathrm{g} .170 \mathrm{G}<\mathrm{A} / \mathrm{R} 105 \mathrm{Q}$ and g.332G $<$ A/R159Q those altering amino acids from arginine to glutamine. This study therefore was aimed to evaluate Leptin gen polymorphism based on those SNPs, and their association with body weight of Padjadjaran sheep.

\section{MATERIALS AND METHODS}

This research used DNAs of one year old of twenty six Padjadjaran sheeps which were reared intensively. The DNAs were isolated from white blood cell by Homebrew method (Davis and Bufone, 1985). The quantity and quality DNA were analyzed by Nanodrop spectrophotometer. The target of $696 \mathrm{bp}$ leptin gene including exon 3, was amplified by PCR using flanked primer forward 5' GGGAAGGGCAGAAAGATAGG3'; reverse 3' GCAGCTGAGAGGAGCAAGAG 5', and was designed by Primer3 Plus. Each PCR reagent was prepared for $25 \mu \mathrm{L}$ of volumes, mixed from: 50 ng DNA template, PCR Master Mix kit, distilled water (DW), and primer F/R.

Multiplication of DNA by PCR machine was started with initial and further denaturation at $94^{\circ} \mathrm{C}$, annealing at $58^{\circ} \mathrm{C}$ and extension at $72^{\circ} \mathrm{C}$. PCR product of leptin gene target was confirmed by gel agarose electrophoresis. The point mutation identifiying as a SNPs, was analyzed by Sanger sequencing. The sequence results and SNPs identification were analyzed by Bioedit and MEGA 7 program. 
The experimental animal was reared in a colony cage, with a capacity of 20 sheep. Animal was offered amixture of concentrates (30\%) and forages $(70 \%)$ as much as $3.5 \%$ dry matter of body weight. The concentrates feed has $13 \%$ of protein and 65-70\% Total Digestible Nutrient (TDN). Drinking water was given an adlibitum. Record of live weight was done monthly, from birth until to one year old.

\section{Data Analysis}

The frequency of alleles and genotypes of leptin gene based on SNPs were calculated with Nei and Kumar (2000): $X_{i}=\left(2 n_{i i}+\sum n_{i j}\right) /(2 N)$.

Where

$\mathrm{X}_{\mathrm{i}}$ : Alleles frequency (i)

$\mathrm{n}_{\mathrm{ii}} \quad$ : Individual number of genotype AiAi

$\mathrm{n}_{\mathrm{ij}} \quad$ : Individual number of genotype AiAj

$\mathrm{N}$ : Sample Total

Association of SNPs with body weight were analyzed by independent $\mathrm{T}$ test by Microsoft excel program.

\section{RESULTS AND DISCCUSION}

The PCR product was amplified include a part of intron $2^{\text {nd }}$, and exon $3^{\text {rd }}$ as long as $696 \mathrm{bp}$ as presented in Figure 1.

\section{The Single Nucleotide Polymorphism in Leptin Gene}

Based on gene bank data (NCBI. Access No. HE605296.1 and AY911719.1). the exon $3^{\text {rd }}{ }^{i_{n}}$ sheep leptin genes translating to amino acids were 357 bp of nucleotides, which encode a number of
119 amino acids. Point mutation on nucleotide sequence in exon as a coding region, may alter amino acids impacting formed polypeptide that was formed. This study showed there were two point mutation in exon 3 of leptin gene i.e. g. $170 \mathrm{G}<\mathrm{A}$ and g. $332 \mathrm{G}<\mathrm{A}$ as illustrated in Figure 2 and Figure 3. Those mutations were non synonimous mutations, altering amino acids from arginine to glutamine on both SNPs, which was caused by base nitrogen substitution from guanine to adenine $(\mathrm{CGG}<\mathrm{CAG})$. Both of mutations were found in same pattern on all of samples, individually had mutation on g. $170 \mathrm{G}<\mathrm{A}$, also having a mutation in g. $332 \mathrm{G}<\mathrm{A}$. Both SNPs on exon 3 led to an amino acid alteration from arginine to glutamine at position R105Q and R159Q. Two SNPs identified in exon 3 were in complete linkage disequilibrium in all samples (visually verified using the genotypes). Allele and genotype frequency of Based on SNPs on Leptin gene of Padjadjaran sheep are presented on Table 1.

Based on SNPs identification, there were two alleles of $\mathrm{G}(0.75)$ and $A(0.25)$ and two genotypes of $\mathrm{GG}$ and $\mathrm{GA}$ with 0.5 frequency, respectively. Frequency of $\mathrm{G}$ allele was higher than A allele. These result is in line with study of Jonas et al. (2016) on crossbreed Awassi Merino sheep that found two nonsynonymous mutation on leptin gene exon 3 i.e. A314G and A476G, both of mutation in exon 3 led to an amino acids at position 105 and 159 change from Arginine to Glutamine. This study generated two alleles, i.e. $\mathrm{G}$ and $\mathrm{A}$, the frequencies 0.83 and 0.17 , further GG and GA genotype 0.92 and 0.08 respectively. Furthermore, Mahmoud et al. (2014) presented on

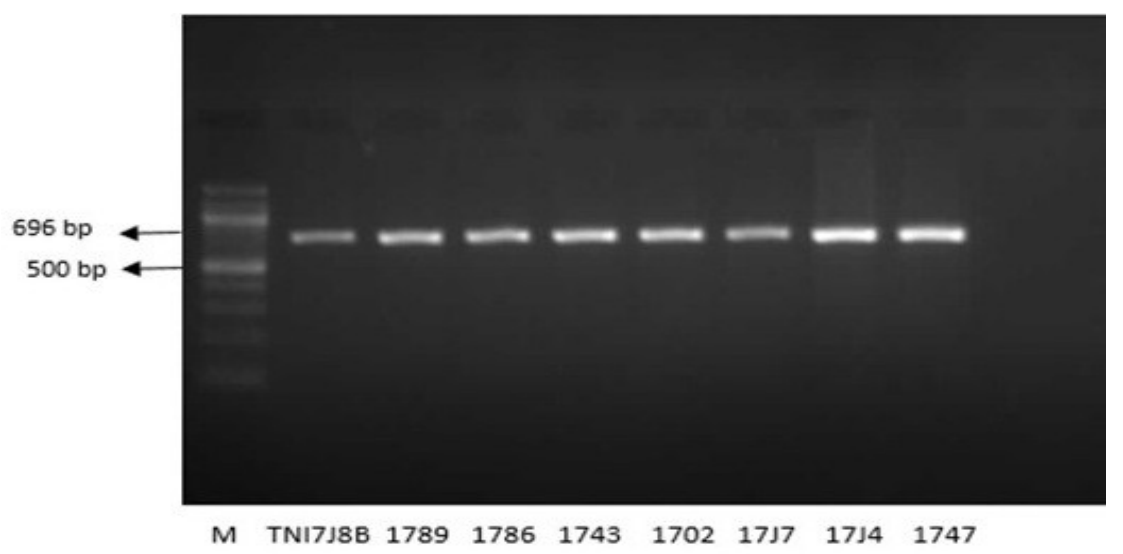

Figure 1. Product of PCR Leptin Gene 696 bp consisted of a part of $2^{\text {nd }}$ and $3^{\text {rd }}$ Intron 


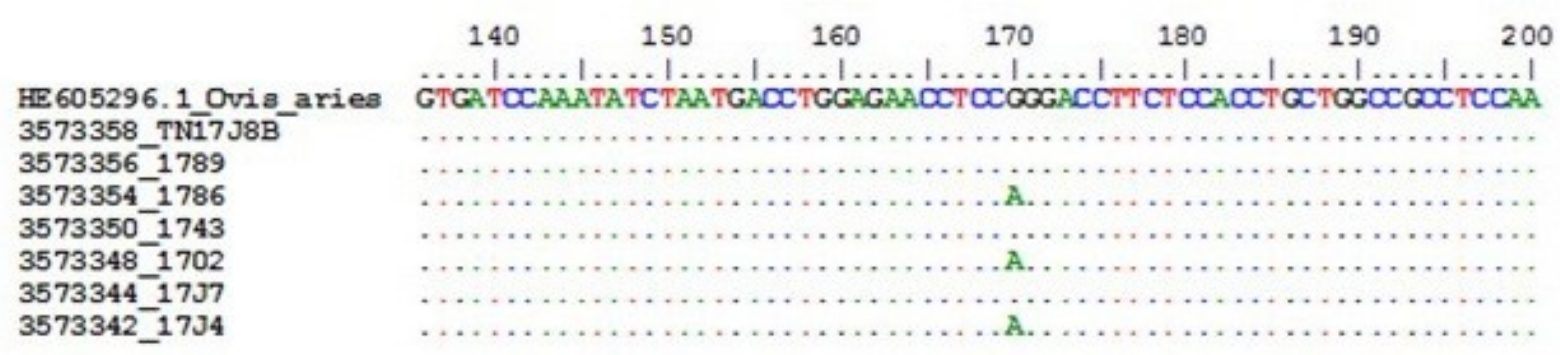

Figure 2. SNP g.172G $<$ A on Padjadjaran Sheep

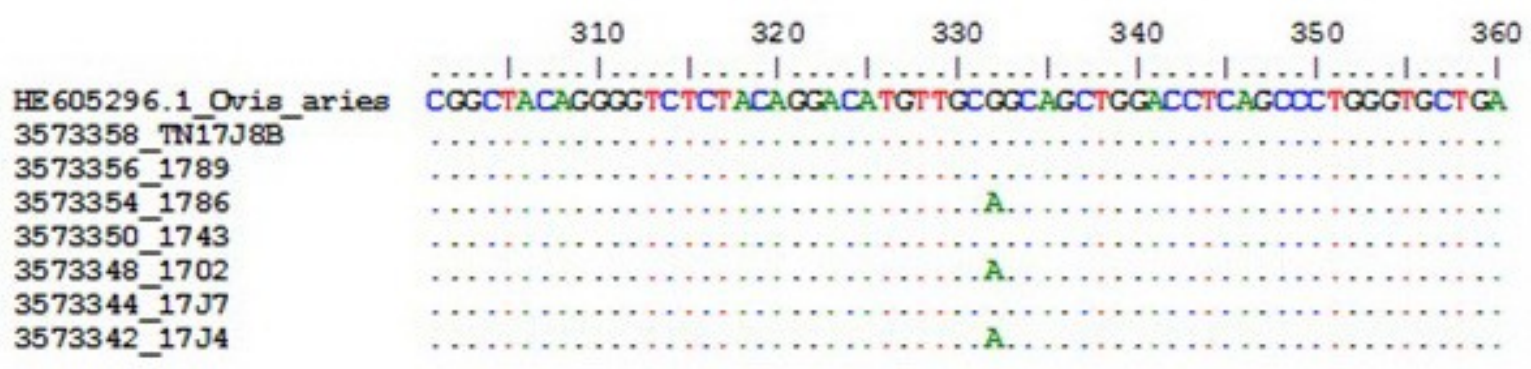

Figure 3. SNP g.332G $<$ A/R159Q on Padjadjaran Sheep

Table 1. Allele and Genotype Frequency Based on SNPs Leptin Gene of Padjadjaran sheep

\begin{tabular}{|c|c|c|c|c|c|}
\hline \multirow{2}{*}{ Sample } & \multirow{2}{*}{$\mathrm{N}$} & \multicolumn{2}{|c|}{ Allele Frequency } & \multicolumn{2}{|c|}{ Genotype Frequency } \\
\hline & & $\mathrm{G}$ & $\mathrm{A}$ & $\mathrm{GA}(13)$ & $\mathrm{GG}(13)$ \\
\hline Padjadjaran Sheep & 26 & 0.75 & 0.25 & 0.5 & 0.5 \\
\hline
\end{tabular}

Najdi and Naeimi as an Arabian sheep, were found two nonsynonymous mutation g. $170 \mathrm{G}<\mathrm{A}$ and g.332G $<\mathrm{A}$ and Zhou et al. (2009) found non synonymous SNP in exon 3 leptin gene which amino acids R105G Arginine was changed to Glutamine. The research of Bakhtiar et al. (2017) on Sanjabi sheep showed that there were nonsynonymous point mutation which were detected by PCR RFLP used BcnI (g.170G $<$ A) and CaiI (g. 332G $<\mathrm{A})$. Moreover Bakhtiar et al. (2017) stated based on mutation g.332 $\mathrm{G}<\mathrm{A}$ there were two allele $\mathrm{G}$ and $\mathrm{A}$, their frequency 0.82 and 0.18 respectively. Three genotypes were GG, GA and AA with frequency $0.68,0.29$ and 0.03 , respectively.

Molecular genetic research of on Ovis aries leptin gene showed that there were many mutation on this gene. The research of Barzehkar et al. (2009) on three breed of Iranian sheep Shal, Zandi and Zel sheep, using detection on the single strand conformational polymorphism (SSCP) technique, presented polymorphisms on exon 2 and part of intron 1. They found two alleles A and $\mathrm{G}$. The frequencies of alleles of $\mathrm{A}$ and $\mathrm{G}$ were $0.74,0.26$ in the Shal breed, $0.85,0.15$ in the Zandi breed and $0.82,0.18$ in the Zel breed. There were two genotypes $\mathrm{AA}$ and $\mathrm{AG}$ with frequencies of 0.53 and 0.47 in the Shal breed; 0.70 and 0.30 in the Zandi and $0.65,0.35$ in the Zel. Hereinafter, the study of Hashemi et al. (2011) declared that there were five distinct patterns in PCR_SCCP exon 3 leptin gene of Makooei sheep, representing five genotypes. The frequencies of the observed genotypes were $0.09,0.17,0.37$, 
0.14 and 0.23 for $\mathrm{BB}, \mathrm{AB}, \mathrm{BC}, \mathrm{AC}$ and $\mathrm{CC}$, respectively. Allele frequencies were $0.15,0.37$ and 0.48 for $\mathrm{A}, \mathrm{B}$ and $\mathrm{C}$, respectively.

Further research, in Malpura sheep indicated allelic variants on leptin gene based on PCRRFLP analysis on 471 bp fragment of the exon 3, three non-synonymous SNPs were found, A271G, $\mathrm{A} 316 \mathrm{C}$, and $\mathrm{T} 387 \mathrm{G}$. Two loci were found monomorphic, while T387G was polymorphic, with two alleles ( $\mathrm{G}$ and $\mathrm{T}$ ), and three genotypes (GG, GT and TT). The allelic frequency of $\mathrm{G}$ and $\mathrm{T}$ allele at $\mathrm{T} 387 \mathrm{G}$ locus were found 0.82 and 0.18 , respectively. Furthermore, Cauveri et al. (2014) stated that LEP gene in Nilagiri sheep was polymorphic, the research was done by PCRRFLP and showed two polymorphisms 16973 $\mathrm{G}>\mathrm{A}($ (SNP-L1) and $17476 \mathrm{C}>\mathrm{T}$ (SNP-L2). Based on SNP-L2 was found that allelic frequencies of C and $\mathrm{T}$ were 0.87 and 0.13 , respectively.

Molecular genetic research of on Ovis aries leptin gene showed that there were many mutation on this gene. The research of Barzehkar et al. (2009) on three breed of Iranian sheep Shal, Zandi and Zel using the detection of single strand conformational polymorphism (SSCP) technique, presented polymorphisms in exon 2 and part of intron 1. They found two alleles $A$ and $G$, frequencies of alleles $\mathrm{A}$ and $\mathrm{G}$ were $0.74,0.26$ in the Shal breed, $0.85,0.15$ in the Zandi breed and $0.82,0.18$ in the Zel breed. There were two genotypes $\mathrm{AA}$ and $\mathrm{AG}$ with frequencies of 0.53 and 0.47 in the Shal breed i.e. 0.70 and 0.30 in the Zandi and 0.65, 0.35 in the Zel. Hereinafter, the study of Hashemi et al. (2011) declared that there were five distinct patterns on PCR_SCCP exon 3 leptin gene of Makooei sheep, representing five genotypes. The frequencies of the observed genotypes were $0.09,0.17,0.37,0.14$ and 0.23 for $\mathrm{BB}, \mathrm{AB}, \mathrm{BC}, \mathrm{AC}$ and $\mathrm{CC}$, respectively. Allele frequencies were $0.15,0.37$ and 0.48 for $\mathrm{A}, \mathrm{B}$ and $\mathrm{C}$ gene, respectively.

Further research, on Malpura sheep indicated allelic variants in leptin gene using PCR-RFLP analysis on $471 \mathrm{bp}$ fragment of the exon 3. This study found three non-synonymous SNPs, A271G, A316C, and T387G. Two loci were found monomorphic, while $\mathrm{T} 387 \mathrm{G}$ was polymorphic with two alleles ( $\mathrm{G}$ and $\mathrm{T}$ ), and three genotypes (GG, GT and TT). The allelic frequency of $\mathrm{G}$ and $\mathrm{T}$ at $\mathrm{T} 387 \mathrm{G}$ locus was found 0.82 and 0.18 , respectively. Furthermore, Cauveri et al. (2014) stated LEP gene in Nilagiri sheep was polymorphic, the research was done using PCRRFLP and showed two polymorphisms 16973
G>A (SNP-L1) and 17476 C $>$ T (SNP-L2). Based on SNP-L2 was found that allelic frequencies of $\mathrm{C}$ and $\mathrm{T}$ were 0.87 and 0.13 respectively.

\section{Assosiation Leptin Gene Polymorphism with Growth.}

Leptin contributed on growth through signals of leptin as an obese hormone with dominant major role in balancing of food intake and energy expenditure to regulate body weight on physiological process (Wasim, 2015). Furthermore, Putra and Indriastuti (2017) reviewed on many result study of leptin gene in cattle, and they stated that there were polymorphisms in leptin gen on promotor, intron and exon, each of these parts is associated with body weight, carcass weight and milk production in cattles.

Growth curve and assosiation of leptin gene polymorphisms with birth weight and monthly weight gain in Padjadjaran sheep are presented on Figure 4 and Table 2.

Present study showed there were no significant $\quad(\mathrm{P}>0.05)$ association between polymorphisme based on SNPs in exon 3 of leptin gene at birth to 12 months of ages on Padjadjaran sheep. This result might be in accordance with study of Tahmoorespur et al. (2010). They stated that there was not significant effect polymorphisms on leptin gene exon 3 to estimated breeding value (EBV) of birth weight, 6 month, 9 month, and yearling weight, while different effect in EBV weaning weight measured at 90 days in Baluchi sheep. Furthermore, research Jonas et al. (2016) in Awassi Merino crossbred reported that leptin dan leptin receptor gene were not significantly associated with body weight, feed intake, milk yield, protein percentage or fat percentage

Many research using sheep showed different results, there were significant effect on leptin gene polymorphism to growth trait, their polymorphism was not in exon $3^{\text {rd }}$. The study of Barzehkar et al. (2009) using Shal and Zandi as Iranian sheep, there was no significant effect of leptin gene polymorphisms to birth weight and average daily gain before weaning age. There was not significant effect SNP A103G to average daily gain (ADG) on Shal, Zandi and Zel sheep, while slaughter weight was significant effect on Zel sheep. The research of Shojae et al. (2010) on 275 bp exon 3 Kermanee sheep, declared there were ten genotypes. $\mathrm{A} / \mathrm{B} / \mathrm{E}, \mathrm{A} / \mathrm{C}, \mathrm{A} / \mathrm{B} / \mathrm{C} / \mathrm{F}$ and $\mathrm{A} / \mathrm{B} / \mathrm{C} / \mathrm{F}$ genotypes with higher body weight at $3,6,9$ and 


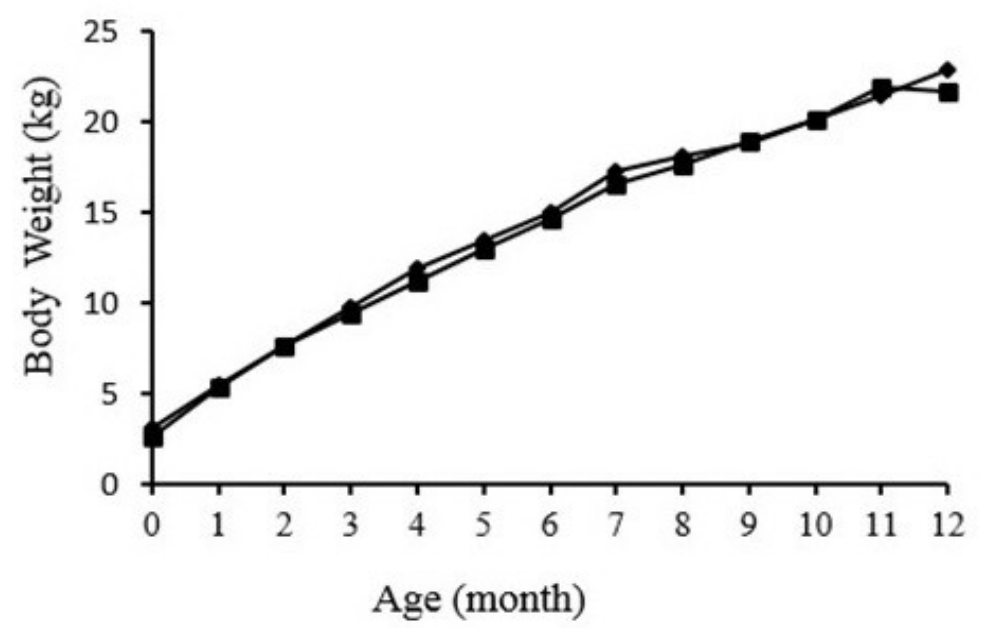

Figure 4. Growth Curve of Padjadjaran Sheep from Birth (0 month) to 12 Month of Age, based on Genotype of Leptin Gene. The Symbols Represent GA genotype ( $\bullet$ ) and GG genotype (ם). Data points are mean values based on 13 samples of each genotype

Table 2. Assosiation Leptin Gene Polymorphism with Monthly Body Weight

\begin{tabular}{cccccccccccc}
\hline \multirow{2}{*}{ Genotype e } & \multicolumn{10}{c}{ Average body weight $(\mathrm{kg})$ at $\mathrm{i}^{\text {th }}$ month } \\
\cline { 2 - 12 } & BW/0 & 3 & 4 & 5 & 6 & 7 & 8 & 9 & 10 & 11 & 12 \\
\hline GA & 5.52 & 9.85 & 11.95 & 13.54 & 15.12 & 17.35 & 18.17 & 18.84 & 20.14 & 21.45 & 22.91 \\
GG & 5.46 & 9.45 & 11.28 & 13.05 & 14.66 & 16.55 & 17.65 & 18.97 & 20.19 & 21.98 & 21.69 \\
Sig & ns & ns & ns & ns & ns & ns & ns & ns & ns & ns & ns \\
\hline
\end{tabular}

$\mathrm{BW} / 0=$ birth weight at 0 month old; $\mathrm{Sig}=$ significance; $\mathrm{ns}=$ non significant $(\mathrm{P}>0.05)$

12 months of ages respectively.

Furthermore, the study of Hajihosseinlo et al. (2012) using Makooei sheep presented a positive effect polymorphisms in leptin gene on growth, genotype L4 (BC) and impacting on 6 month of weight, additive estimated breeding value for the weaning weight, 6 month weight, average daily gain from weaning to 6 month (GWS). In addition, the animal with genotype L4 (BC) had a superior performance for total traits and also the genotype L3 (AC) had a superior birth weight when compared to those of individuals with other pattern. Generally, the BC genotype and $\mathrm{B}$ allele were improved growth traits than other genotypes and alleles in Makooei sheep and the estimated effects suggest that most of the impact of LEP is realized after weaning. Further the research of Saleem et al. (2018) on 18
Lohi sheep revealed single nucleotide polymorphism ( $\mathrm{T}>\mathrm{A}$ at position 483 ) and a heterozygous condition ( $\mathrm{T}>\mathrm{W}$ at position 483) The variation i.e. "W" type heterozygous condition showed a higher average daily weight gain. Sequence analysis of LEP gene confirmed the presence of genetic variability among Lohi animals; this variation might be associated with other economic traits for future breeding programs and marker assisted selection.

There was no significant effect of leptin gene polymorphisms on body weight in these research, assuming growth relate to cell proliferation, hypertrophy and fat deposition. Many hormones which were encoded by gene had an impact to those aspects, include Growth Hormone (GH), Insulin-like Growth Factor (IGF), Growth Hormone Receptor (GHR), myostatin, leptin and 
others. Furthermore, gene mutations will be expressed if environmental conditions are supporting, including feeding. The relationship between the expression of leptin gene mutations with the quality and quantity of feed related to nutrigenomic theory. Nutrigenomics can be interpreted broadly that food nutrition is able to change gene expression either directly or indirectly affecting protein expression, metabolic status and / or has an influence on cells, tissues, organs or parts of an organism's body (Bionaz, 2015).

\section{CONCLUSION}

Leptin gene in Padjadjaran sheep was polymorphic. There were two SNPs on exon $3^{\text {rd }}$, namely g.170G $>$ A/R105Q and g.332.A $>$ G/R159Q. Both of these mutations are non-synonymous mutations, altering amino acids from Arginine to Glutamine. The alleles frequency of $\mathrm{G}$ and $\mathrm{A}$ were 0.75 and $A 0.25$, respectively, and genotype frequency, $\mathrm{AG}$ and $\mathrm{GG}$ was 0.5 . There was no association between Single Nucleotide Polymorphisms in leptin gene with body weight from birth to 12 month of age.

\section{ACKNOWLEDGMENTS}

The authors would like to thank the Directorate of Research and Community Service of Universitas Padjadjaran which has funded this research in the Academic Leadership Grant Scheme (ALG), Contract number 3167/UN6.J/LT/2018

\section{REFFERENCES}

Bakhtiar, R., A. Abdolmohammadi, H. Hajarian, Z. Nikousefat, Davood and K. Neyestanaki. 2017. Identification of $332 \mathrm{~g}>\mathrm{a}$ polymorphism in exon 3 of the leptin gene and partially effects on body size and tail dimension in Sanjabi sheep. World Academy of Science Engineering and Technology. Intl. J. of Bioengine and Life Sci. 11(7): 506-509.

Barzehkar, R., A. Salehi and F.Mahjoubi. Polymorphisms of the ovine leptin gene and its association with growth and carcass traits in three Iranian sheep breeds. 2009. Iranian J. Biotech. 7(4):241-246.

Bionaz, M., J. Osorio and J.J. Loor. 2015. Nutrients, transcription factors, and techniques. Nutrigenomics in dairy cows.
Triennial Lactation Symp. J. Anim. Sci. 93(12):5531-5553.

Cauveri, D., S.N. Sivaselvam, S.M.K. Karthickeyan, K.G. Tirumurugaan and K. Kumanan. 2014. Allelic polymorphism of exon 3 of leptin gene in ilagiri sheep identified by sequencing and PCR-RFLP. Intl J. Sci. Environ and Tech. 3(3): 951-955.

Foote, A.P., K.E. Hales, L.A. Kuehn, D.H. Keisler, D.A. King, S.D. Shackelford, T.L. Wheeler and H.C. Freetly. 2015. Relationship of leptin concentrations with feed intake, growth, and efficiency in finishing beef steers. J. Anim. Sci. 93:44014407.

Hajihosseinlo, A., A. Hashemi and S. Sadeghi. 2012. Association between polymorphism in exon 3 of leptin gene and growth traits in the Makooei sheep of Iran. Livestock Res. Rural Dev. 24 (9):543-546.

Hashemi, A., K. Mardani, M. Farhadian, I. Ashrafi and M. Ranjbari. 2011. Allelic polymorphism of Makoei sheep leptin gene identified by polymerase chain reaction and single strand conformation polymorphism. Afr. J. Biotech. 10 (77): 17903-17906.

Jonas, E., G.B. Martin, P. Celi, L. Li, M. Soattina, P.C. Thomsona and H.W. Raadsmaa. 2016. Association of polymorphisms in leptin and leptin receptor genes with circulating leptin concentrations, production and efficiency traits in sheep. Small Rum. Res. 136:78-86.

Mahmoud, A. H., A.A. Saleh, N.A. Almealamah, F.M. Abou-tarboush, R.S. Aljumaah, T.M. Shafey and M.A. Abouheif. 2014. Molecular Characterization of Leptin Exon 3 gene in sheep of Saudi Arabia. Res. J. Biotech. 9(7):32-35.

Nei, M. and S. Kumar. 2000. Molecular evolution and phylogenetics. $1^{\text {st }}$ ed. USA: Oxford University Press.

Sáinz, N., J. Barrenetxe, M.J. Moreno-Aliaga and J.A. Martínez. 2015. Leptin resistance and diet-induced obesity: central and peripheral actions of leptin. J. Metab. Clin Exp. 64:3546.

Saleem, A.H., J. Khalid, E.B. Masroor, T. Hussain, A. Ali, A. Ali, N. Ahmad, M.Z. Farooq and M. Dawood. 2018. Association of leptin gene polymorphism with growth rate in Lohi sheep. Pakistan J. Zoo. 50(3):1029-1033.

Shojaei, M., M.M. Abadi, M.A. Fozi, O. Dayani, A. Khezri and M. Akhondi. 2010. 
Association of growth trait and leptin gene polymorphism in Kermani sheep, J. Cell Mol. Res. 2(1):67-73.

Tahmoorespur, M., A. Taheri, M.V.V.D.A. Saghi and M. Ansary. 2010. Assessment Relationship Between Leptin and Ghrelin Genes Polymorphisms and Estimated Breeding Values (EBVs) of Growth Traits in Baluchi Sheep. J. Anim. Vet. Adv. 9 (19):2460-2465.

Wasim, M. 2015. Role of Leptin in Obesity. J. Obes. Weight. Loss. Ther. 5(258):1-3.

Woronuk, G.N, F.L. Marquess. S.T. James, J. Palmer, T. Berryere, H. Deobald, S. Howie and P.J. Kononoff . 2012. Association of leptin genotypes with beef cattle characteristics. Anim. Genet. 43(5):608-610.

Zhou, H., H. Hickford and H. Gong. 2009. Identification of allelic polymorphism in the Ovine leptin gene. Mol. Biol. 41:22-25.

Wang, C., H. Zhang, L. Niu, J. Guo, X. Jia, L. Wang, L. Li, H. Zhang and T. Zhong. The novel SNPs of leptin gene and their associations with growth traits in Chinese Nanjiang Yellow goat. GENE. 572(1):35-41.

Putra, W.P. and R. Indriastuti. 2017. Gen leptin sebagai gen potensial untuk seleksi molekuler pada sapi di Indonesia. Wartazoza. 27(3):105-106. 